\title{
A Study on the Performance of Public Distribution System With Reference To Colachel Municipality
}

\author{
Bhagyasree PG \\ Department of Economics, PSGR Krishnammal College for Women, Coimbatore, India
}

\begin{abstract}
India has one of the highest levels of malnutrition in the world and there are reports of hunger and starvation deaths from different parts of the country. A staggering five percent of rural and two percent of urban population do not get food throughout the year. In order to meet the food security needs government implemented Public Distribution System but in due course of time several leakages were found in distribution of Public Distribution System. The current study aims to analyze the socio economic background of rural population brought under study area, their perception and utilization level towards PDS commodities.
\end{abstract}

Key Words: Food Security, Public Distribution System, Problems in access, utilization and perception of PDS goods

\section{Introduction \\ "Share the food and serve all lives \\ This is the cardinal principal of equity"}

Thirukural 322

Food production has increased more steadfastly than population, which has been evidenced through scientific research. Against this, reality hunger still persist in many parts of the world. About 795 million people are undernourished globally, down 167 million over the last decade, and 216 million less than in 1990-92. Food Security stands as a fundamental need, basic to all human needs and organization of human life.

In order to meet the onerous responsibility of providing food security to its citizens, the country has launched a host of programmes to increase production of food grains, generate employment to increase income level of families and to meet the nutritional needs of vulnerable groups. But, in spite of all Governmental efforts, the country has one of the highest levels of malnutrition in the world and there are reports of hunger and starvation deaths from different parts of the country. According to the report of Food and Agricultural Organization (FAO) of the United Nations, number of hungry people in India had been reduced from 261.5 million in 1979-81 to 194.6 million in 2014-15.The concept of food security is interlinked with a number of related factors such as agricultural policy, nutritional policy, access to education, health care, potable drinking water, sanitation, employment security, social security and the system of public distribution through fair price shops.

\subsection{Public Distribution System In India: An Overview}

The root of food security through PDS goes to Kautilyan 'Arthashastra'.According to Kautilya "social security was both a private and a state matter". The history behind introduction of the PDS in India is rooted in famines and food scarcities during the entire period of British colonial rule in the most important medium through which the Government ensures food security at the micro-level is the Public Distribution System (PDS). The main purpose of the Public Distribution System (PDS) in India was to act as a price support programme for the consumer during the periods of food shortage of the 1960s. The objectives of the Government of India's food security policy are,

(i) Ensuring adequacy or sufficiency in supply of food grains, and

(ii) Distributing food grains at an affordable price.

In India, targeting was more focused during the nineties, first, Revamped Public Distribution System (RPDS) has been initiated by the Government of India from the year 1992 in order to serve and provide essential commodities to the people living in remote, backward and hilly areas. Government introduced Targeted Public Distribution System (TPDS) in the year 1997. Major commodities distributed include staple food grains, such as wheat, rice, sugar and kerosene, through a network of public distribution shops (also known as ration shops) established in several states across the country at reasonable prices. Tamil Nadu sets a model in implementing the PDS as universal system for the cause of eradicating poverty and improving standard of living of the people living below the poverty line. 
1.2 Objectives

The objectives of the study are,

1. To study the socio- economic conditions of rural population brought under PDS

2. To evaluate the issues related to access, utilization and perception of PDS among APL and BPL beneficiaries.

3. To study the benefits derived out of PDS

1.3 Field Of Study

The present study on Public Distribution System has been carried out in Colachel -Municipality of Kalkulam Taluk in Kanyakumari district. Kalkulam Taluk consist of 242 PDS shops. Of which Colachel Municipality covers 9 shops. The number of beneficiaries of PDS in Colachel Municipality is around 23,227 households.

\subsection{Methodology Of The Study}

The study is empherical in nature and based on primary and secondary data. The primary data is collected from the sample surveys of the family card holders using questionnaires, Sample size was confined to 64.The secondary data has been collected from books, journals, magazine, newspaper, periodicals, reports and websites.

\subsection{Limitations Of The Study}

The present study is subjected to the following limitations:-

1. The primary data used in this study have been collected only from PDS beneficiaries. It is difficult to analyze the performance of PDS in the study area with limited sample size and the reliability of data is based on response of the beneficiaries.

2. The study pertains to a limited time period.

\section{Review Of Literature}

George (1996), attempted to analyze public distribution of food grains and their income distribution effects in Kerala. He tried to estimate the possible impact of rationing on incomes of the consumers using the relationship. The results for Kerala suggest that the system is economically viable. Further, ration rice, according to this study, accounted for a major share of rice consumption of consumers belonging to low income groups. Ray et al. (2011), analyzed the food security issue of India during the last few decades and working of PDS with some macro measures. Their paper also tries to identify the part of population who deserve food security in general. They also analyze the availability, storage and procurement of food grains, assess the effectiveness of PDS, identify the discrepancies in the system, and find ways to remove the anomalies and to make the delivery mechanism more efficient. They mentioned that the targeting of individuals as a part of PDS has not been able to solve the problem of hunger. The exclusion of genuine beneficiaries has led to collapse of the objective of providing food security to the needy. They suggest that states should be given better flexibility in designing their own food security system and strong social audit mechanisms must be put in action.

Bhatt et al. (2012), attempted to study the efficiency of PDS in Kashmir. They found a lot of misappropriation in supplies of PDS. They observed that ration shop owners had less profit and often sold their goods in the open market to earn more. The ration shops owners were also involved in misappropriation of supplies and provided much less to the consumers. The supplies were also of lower qualities and were not provided to the beneficiaries on time. The study suggested that proper monitoring should be in place so that corruption could be minimized. They proposed that a minimum level of social security must be provided to the old, sick and disabled so as to ensure they do not go hungry. Arora (2013), examined food subsidy in India and analyzes reasons behind the failure of PDS in many parts of the country. The article utilizes the 61st round of National Sample Survey Data on the monthly consumptions of households for the year 2004-05 and examines the role of Public Distribution System in ensuring price stability. The study pointed that the two major objectives for initiating this food security program was to provide nutritional support to the poor through subsidized and cheap food grains and maintain price stability, it has largely failed in meeting its goals. It has failed to reach the poor in most of the states other than the southern states like Andhra Pradesh, Tamil Nadu and Kerala, where it has been partially successful. To improve the functioning of the system it is imperative to improve outreach, particularly in the Northern states of the country and also suggested on inclusion of banks in providing food security

\section{Evolution Of Public Distribution System}

The Public Distribution system in India forms an important part of state strategy intervening in the distribution of food grains and other essential commodities. The major causes of the origin of this policy are (i) Drought, famine and war conditions, (ii) Inflation, (iii) Market imperfections, (iv) Poverty and (v) Lack of distributive justice. The PDS has been an integral part of India's overall food policy. It has been instrumental in mitigating the plight of the masses that are burdened by low income inflationary conditions, scarcities and the haunting fear of adulteration. 
Interest of the vulnerable sections of the society must be taken care of in the supply of food grains and essential commodities. The fact is, that PDS has been covering all sections of both urban and rural people irrespective of income. During the period from September 1939 to September 1942, the British Government convened Six Price Control Conferences. Price control was introduced in India in 1941. The controlled distribution of food grains became necessary after the fall of Burma, the most important supplier of rice to India, in March 1942. The importance of linking price control, with the control on distribution of food grains, was stressed by the Fifth Price Control conference held in April 1942.

The British Government issued the Food grains Control Order on May 21, 1942, covering major food grains (wheat, rice and barley), but subsequently the coverage was extended to pulses and millets as well. From 28th May 1942, the features and options in wheat and grams were prohibited as anti-speculative measures, save with the permission of the Central Government or an authorized office, throughout British India. The attitude of the British Government towards the Quit India Movement as well as the Japanese threat further worsened the food situation during December 1942. The Government of India established the Food Department, with a view toIntegrate all the activities relating to purchase, distribution and movement of food grains on all basis. In July 1943, the First Food grains Policy Committee, under theChairmanship of Dr. Theodore Gregory, was appointed and entrusted with the task of recommending a sound and effective food policy for the subsequent years. Its recommendations emphasized the need for increased supply, improved procurement machinery, execution of rationing, statutory price control, overhauling of the administrative machinery and a closer co-operation between the centers, provincesand princely states. The Food Grain Enquiry Committee recommended the need for price stabilization, control over trade of food grains and its "Progressive Socialization". The Committee was of the opinion that full control of food grain market was neither desirable nor feasible. Instead, the committee suggested open-market purchases of the wholesale trade and regular imports of rice and wheat to meet local consumption requirements.

A new phase of public distribution system emerged in 1969, exactly after 30 years of its beginning. The Fourth Five Year Plan set out the guidelines for public distribution system. The main feature of this scheme was the creation of buffer stock of adequate size to meet the needs of Public Distribution System.In January 1992, after the implementation of the New Economic Policy, the Rao Government launched a special scheme called Revamped the Public Distribution System (RPDS) which aimed to serve in a more efficient way to the tribal, hill and arid area populations located in remote areas and having poor infrastructure. Under this scheme, food grains are allocated to states for the proposed geographical coverage of RPDS blocks at prices lower by 50 paise $/ \mathrm{kg}$ than the issue price for the normal PDS. The retail price at the RPDS shops is not supposed to be higher than the Central Issue Price (CIP) by more than 25 paise/Kg.1.

\subsection{Present Public Distribution System}

Public distribution system (PDS) is an Indian food security system. Established by the Government of India under Ministry of Consumer Affairs, Food, and Public Distribution and managed jointly with state governments in India, it distributes subsidized food and non-food items to India's poor. This scheme was launched in India on June 1997. Major commodities distributed include staple food grains, such as wheat, rice, sugar, and kerosene, through a network of public distribution shops (also known as ration shops) established in several states across the country. Food Corporation of India, a Government-owned corporation, procures and maintains the PDS. Subsequently, in 1997, the government launched the Targeted Public Distribution System (TPDS), with a focus on the poor. TPDS aims to provide subsidized food and fuel to the poor through a network of ration shops. Food grains such as rice and wheat that are provided under TPDS are procured from farmers, allocated to states and delivered to the ration shop where the beneficiary buys his entitlement. The centre and states share the responsibilities of identifying the poor, procuring grains and delivering food grains to beneficiaries. In September 2013, Parliament enacted the National Food Security Act, 2013. The Act relies largely on the existing TPDS to deliver food grains as legal entitlements to poor households. This marks a shift by making the right to food a justiciable right. In order to understand the implications of this Act, the note maps the food supply chain from the farmer to the beneficiary, identifies challenges to implementation of TPDS, and discusses alternatives to reform TPDS. It also details state-wise variations in the implementation of TPDS and discusses changes to the existing system by the Act.

\subsection{Categories Of Public Distribution System In India}

The following sections reveal the changes in the system since independence and discuss their implications.

- Revamped Public Distribution System (RPDS)

- Targeted Public Distribution System (TPDS)

- PDS for General BPL

- $\quad$ PDS for APL

- Antyodaya Anna Yojana (AAY) 
- Annapurna Yojana

\subsection{Public Distribution System In Tmil Nadu}

The Government of Tamil Nadu is implementing PDS since the year 1964. The scheme Village Shop Programme was introduced by the State with the intention to have one shop for one village in order to feed essential articles to rural public. Subsequently the scheme was converted into PDS with the intention of providing essential commodities to the public both in rural and urban areas at concession rate. Since the introduction of TPDS from 1.6.1997 the universal PDS is in operation in Tamil Nadu with the Antyodaya Anna Yojana and the expanded Antyodaya Anna Yojana schemes. Under the universal PDS there is no discrimination of families on APL and BPL lines based on income. Tamil Nadu sets a model in implementing the PDS as universal system for the cause of eradicating poverty and improving standard of living of the people living below the poverty line.

All Commodity cards (Green): Issued to those cardholders opting for rice as well as all other essential commodities. Sugar cards (White): Issued to cardholders opting for sugar instead of rice. Cardholders can buy all other essential commodities, except rice. Sugar card holders are eligible to get an additional $3 \mathrm{~kg}$. Of sugar in lieu of rice. No commodity cards (White): Issued to cardholders who do not want any commodity under Public Distribution System.

\section{Analysis \& Findings Of The Study}

Table 4.1 Socio Economic profile

\begin{tabular}{|c|c|c|c|c|}
\hline S.no & \multicolumn{2}{|c|}{ Determinants } & No of Respondents & Percentage (\%) \\
\hline \multirow[t]{7}{*}{1} & \multirow[t]{7}{*}{ Age } & $30-40$ & 4 & 6.2 \\
\hline & & $40-50$ & 13 & 20.3 \\
\hline & & $50-60$ & 16 & 25.0 \\
\hline & & $60-70$ & 12 & 18.8 \\
\hline & & $70-80$ & 11 & 17.2 \\
\hline & & $80-90$ & 7 & 10.9 \\
\hline & & Above 90 & 1 & 1.6 \\
\hline \multirow[t]{4}{*}{2} & \multirow[t]{4}{*}{ Education } & Illiterate & 20 & 31.2 \\
\hline & & Primary & 12 & 18.8 \\
\hline & & Secondary & 19 & 29.7 \\
\hline & & Graduate & 13 & 20.3 \\
\hline \multirow[t]{4}{*}{3} & \multirow[t]{4}{*}{ Occupation } & Daily Wage & 25 & 39.06 \\
\hline & & Farmer & 6 & 9.4 \\
\hline & & Business & 15 & 23.4 \\
\hline & & Others & 18 & 28.1 \\
\hline \multirow[t]{3}{*}{4} & \multirow[t]{3}{*}{ Annual Income } & below 30000 & 3 & 4.7 \\
\hline & & $30000-50000$ & 40 & 62.5 \\
\hline & & Above 50000 & 21 & 32.8 \\
\hline \multicolumn{4}{|c|}{ Total } & 100 \\
\hline
\end{tabular}

- The study reveals that 25 per cent of the sample respondents belong to the age group of between 50-60 years.

- The study found that majority of the respondents in the sample area were illiterates ( 31.2 per cent) and 18.8 per cent (12 respondents )had completed primary education, 29.7 per cent (19 respondents) had completed secondary school level, 20.3 per cent (13 respondents) were graduates.

- The study reveals that majority of the sample respondents 39.06 per cent ( 25 respondents) were daily wage earners.

- The study found out that only 4.7 per cent of the respondents belong to income group below 30000

Table 4.2 Utilization and Access of PDS Commodities

\begin{tabular}{|c|c|c|c|c|}
\hline S no & \multicolumn{2}{|c|}{ Determinants } & No of respondents & Percentage (\%) \\
\hline \multirow[t]{2}{*}{1.} & \multirow[t]{2}{*}{ Type of card } & APL & 34 & 53.1 \\
\hline & & BPL & 30 & 46.9 \\
\hline \multirow[t]{2}{*}{2.} & \multirow[t]{2}{*}{ Possession of card } & Self & 63 & 98.4 \\
\hline & & Others & 1 & 1.56 \\
\hline \multirow[t]{4}{*}{3.} & \multirow[t]{4}{*}{ Regularity of Purchase } & Once in a Month & 54 & 84.4 \\
\hline & & Twice a Month & 6 & 9.3 \\
\hline & & More than two & 3 & 4.7 \\
\hline & & Occasionally a year & 1 & 1.6 \\
\hline \multicolumn{4}{|c|}{ Total } & 100 \\
\hline
\end{tabular}




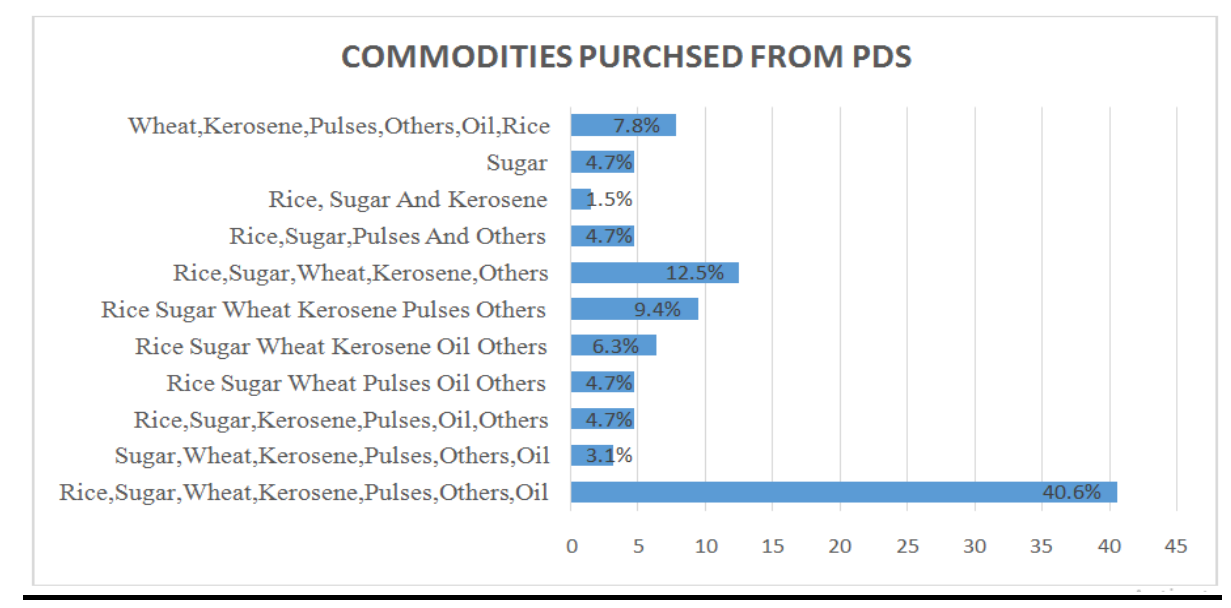

- It was found that out of the total sample 46.9 per cent of the respondents belong to the BPL type of card.

- It was found that majority of the respondents, in all categories had membership with PDS for more than 5years.

- The study revealed that 98.4 per cent of the respondents used card for self-consumption purposes and 1.56 per cent alone used their card for a third person without any monetary obligation.

- It was found that 98.4 per cent of the respondents were regular in their monthly PDS purchase.

- Out of the sample respondents 1.6 per cent occasionally purchases s from PDS and it was observed due to reasons like unwillingness to purchase due to poor quality and to avoid card getting terminated.

- It was found from the study that rice holds primary importance when compared with the two other products, namely, wheat and kerosene, because people here are predominantly consumers of rice and very little wheat. On an average respondents receive $20 \mathrm{kgs}$ of rice every month which is free of cost, $2 \mathrm{kgs}$ of sugar, $3 \mathrm{kgs}$ of wheat and $3-5$ litres of kerosene depending on gas cylinder connection.

- It was found that all sections of people have used PDS articles and the lower price was the motivating factor.

- 43.7 per cent of the respondents were satisfied with the quality of goods supplied by PDS, and 20.3 per cent of the respondents were unsatisfied with the quality of goods supplied by PDS.

- 17.2 per cent of the respondents were unsatisfied with the availability of PDS commodities.

- Majority of the sample respondents 42.2 per cent were unsatisfied on the on quantity of goods supplied by PDS.

- The study reveals that the supply of rice, wheat, sugar, kerosene under PDS is adequate to the family. But the supply of pulses and palm oil is not adequate to the PDS beneficiaries. The fact that grains provided by the PDS was not sufficient to meet family needs was another important factor which makes them to buy from open market at high market price.

- It was observed that out of the total sample 51.5 percent of the respondents availing the PDS benefits suffer from the problem of inconvenient location of PDS outlets.

- It was found that 37.5 per cent of the respondents strongly agree to the problem untimely supply of commodities in PDS outlets.

- It was found that out of the total sample, 46.9 per cent of the respondents agree to the problem of supply of old stocks in PDS resulting in irregular purchase of commodities.

- It was observed 25 per cent of the respondents strongly agree to the problem of improper working hours as another main reason for irregular purchase of commodities from PDS. Though it is observed that the PDS shops are supposed to work from $9.30 \mathrm{am}-1 \mathrm{pm}$ and $2.30-5 \mathrm{pm}$, they are not working as per schedule regularly. Moreover PDS shops also does not operate during weekends thereby creating inconvenience for the people. Most of the PDS come to know about the supply of PDS commodities in the concerned ration shop only through their friends and relatives.

- From the study it was observed that 65.6 per cent of the respondents were satisfied with the overall functioning of PDS and 34.3 per cent of the respondents were unsatisfied with the overall functioning of PDS and the observed reasons were due to inadequate supply, faulty weights etc.

\section{Hypothesis Testing}

1. Level of family income of the household and the type of card they possess.

$\mathrm{H}_{0}=$ there is no significant relationship between the level of family income of the household and the type of card they possess 


\section{Annual Income}

\begin{tabular}{|l|l|l|l|}
\hline & Observed N & Expected N & Residual \\
\hline BELOW 30000 & 3 & 21.3 & -18.3 \\
\hline $30000-50000$ & 40 & 21.3 & 18.7 \\
\hline $30000-50000$ & 21 & 21.3 & -.3 \\
\hline TOTAL & & \\
\hline
\end{tabular}

\begin{tabular}{|l|l|l|l|} 
Beneficiary & Observed N & Expected N & Residual \\
\hline YES & 64 & 64.0 & .0 \\
\hline Total & $64^{\mathrm{a}}$ & & \\
\hline
\end{tabular}

Test Statistics

\begin{tabular}{|l|l|}
\hline & ANNUAL INCOME \\
\hline Chi - Square & $32.094^{\mathrm{a}}$ \\
\hline Df & 2 \\
\hline Asymp. Sig & .000 \\
\hline
\end{tabular}

From the table it can be interpreted that for the calculated value of Chi Square $\chi 2=32.094$ the significance value is lesser than .050, the null hypothesis is rejected and therefore there is a significant relationship between the level of family income of the household and the type of card they possess.

2. Relationship between the type of card and Commodities purchased

$\mathrm{H}_{0}$ = there is no significant relationship between the type of card and Commodities purchased

\section{Descriptives}

Commodities Purchased From PDS

\begin{tabular}{|l|l|l|l|l|l|l|l|l|}
\hline & $\mathrm{N}$ & Mean & $\begin{array}{l}\text { Std. } \\
\text { Deviation }\end{array}$ & Std. Error & \multicolumn{2}{l}{$\begin{array}{l}95 \% \text { confidence interval } \\
\text { for mean }\end{array}$} & Minimum & Maximum \\
\cline { 5 - 7 } & & & & & & & \\
\hline APL & 34 & 3.91 & 3.604 & .618 & 2.65 & 5.17 & 0 & 11 \\
\hline BPL & 30 & 3.10 & 3.916 & .715 & 1.64 & 4.56 & 0 & 11 \\
\hline Total & 64 & 3.53 & 3.746 & .468 & 2.60 & 4.47 & 0 & 11 \\
\hline
\end{tabular}

ANOVA

Commodities Purchased From PDS

\begin{tabular}{|l|l|l|l|l|l|}
\hline & Sum of Squares & Df & Mean Square & F & Sig. \\
\hline Between Groups & 10.502 & 1 & 10.502 & .745 & .391 \\
\hline Within Groups & 873.435 & 62 & 14.088 & & \\
\hline Total & 883.938 & 63 & & & \\
\hline
\end{tabular}

From the table it can be interpreted that for the calculated value, the significance level is greater than .050 , the hypothesis is accepted and therefore there is no significant relationship between the type of card and Commodities purchased from PDS . It is observed irrespective of the type of card there is a greater usage of card for purchase of commodities and this might be due to certain reasons like low cost food grains and also occasionally purchase of commodities from PDS in order to avoid termination of ration card which is a valid document.

\section{Suggestion}

* A monitoring mechanism, through the effective involvement of not only panchayat members but also other sections of society, such as members of youth clubs, self-help groups and MahilaMandals, need to be evolved. This would prevent exclusion of genuine beneficiaries, proper functioning of the fair price shops and control diversion of food grains.

* Information must reach the cardholders well in advance per period (month) regarding arrival and distribution of items through the FPSs

* There has to be regular distribution of oil and pulses allotment very month and quantity allotted should be sufficient.

* Quality of items released from the Supply Department for distribution through FPSs should be improved.

* Late delivery of items (by the Supply Department) should be made regular. The full monthly quota of food grains must reach the Fair Price Shops within seven days of a month to ensure and enable the family card holders to get their entitlements at right time.

* More necessary items included in the PDS list rather than the items which are generally provided. 
* The role of vigilance committees should be made transparent, accountable and responsible for proper and efficient working of PDS. This can be done by appointing independent Regulator/Ombudsman.

* A local committee may be constituted consisting of members of the local body, representative of the family card holders and members of consumer forums for every Fair Price Shops and entrusted with the responsibilities to supervise their working and may be given sufficient powers to handle the local problems.

* Computerization of ration card data for proper distribution and to check leakages should be adopted. This can reduce malpractices in allotment to a greater extend.

* Rampant supply of illegal cards to multiple family members of the same households; this has to be corrected, so that the benefits of PDS go directly to the real beneficiaries.

* Careful attention needs to be paid to 'E' mistakes (exclusion of deserving persons) and 'I' mistakes (inclusion of non-deserving persons) while selecting beneficiaries of BPL, APL categories.

* In addition to supply of essential consumable commodities at FPS, agricultural inputs like improved seeds, fertilizers etc. may also be made available to the farmers which would be very helpful for them to access, as they may purchase the inputs along with commodities under PDS.

* Family card holders must be made aware of Online Grievance Registration System, District Dispute Redressal; Forum, authorities responsible to address their grievances and so on. Awareness campaign in this regard may be carried out in routine manner.

\section{Conclusion}

Rationing was introduced in India as a food control during the Second World War but has come to stay as a permanent feature of our economy as clearly stated in this study. Today the PDS is intended not only to ensure adequate and timely availability of essential commodities to people in the rural and urban areas, particularly the weaker section. Universal coverage is the aim of PDS in Tamil Nadu. State Government is making all efforts to make the PDS more effective by ensuring the availability, affordability and accessibility of PDS articles to the poor. This study presented information about the PDS, details of its working, network, access, and utilization and satisfaction of family card holders towards PDS in Colachel Municipality. The prime aim of PDS is to ensure adequate supply of essential commodities of acceptable quality at an affordable price to general public, particularly the poor. It is true that PDS has achieved greatly in its objectives. But over the decades, its functioning has suffered due to inefficient management. The main aim of the government is pass on huge amount of subsidy it sanctions to the intended people for the intended purpose at low cost. In order to ensure greater efficiency concentration must be made on Targeted Public Distribution System (TPDS) and also application of computer, network technology along with a vigilant administration can equip government better to face the challenge successfully.

\section{Reference}

\section{Books}

[1] Soundarapandian, M., "Economic Reforms and Public Distribution System”,

[2] Serials Publications, New Delhi, 2002

[3] Grover R.K, “Public Distribution System; A Socio Economic Analysis”, Classical Publishing Company, New Delhi, 1998. Journals

[4] Ahluwalia, D "Public Distribution of Food in India: Coverage, targeting and leakages” Food Policy (1993), 18(1), p. 33-54.

[5] Arora, R. U, "Food Subsidies for the Poor in India: Are they Working?” Journal of Asian Public Policy, (2013), 6(3).

[6] Bhat, G. M., \&Hussain, B. A, "Efficiency of Public Distribution System in Kashmir: A Micro Economic Analysis" (2012)

[7] George P.S., "Public Distribution System Food Subsidy and Production Incentives", Economic and Political Weekly, Vol. XXXI, No. 39, September 28, 1996, p.140.

[8] Ghosla, (1992) “India's food scenario by 2000”'Yojana March 1992 (vol 36) p.5

[9] Johan, R., Gaiha, R., Pandey, M. K., \&Kaicker, N. "Food subsidy, Income Transfer and the Poor: A Comparative Analysis of the Public Distribution System in India's States" Journal of Policy Modeling, (2013), 35(6), p.887-908.

[10] KheraR, “Access to the Targeted Public Distribution System: A Case Study in Rajasthan” Economic and Political Weekly, (2008), p. 51-56.

[11] Khosla, R “Caste, Politics and Public Good Distribution in India: Evidence from NREGS in Andhra Pradesh" Economic \& Political Weekly, (2011), 46(12), p.63.

[12] Mooij, J"Food policy and politics: The Political Economy of the Public Distribution System in India" The Journal of Peasant Studies, (1998), 25(2), p.77-101.

[13] Mooij, J. "Food and Power in Bihar and Jharkhand: PDS and its Functioning "Economic and Political Weekly, (2001), p. 32893299.

[14] MahendraDev, “Food Security: PDS vs. EGS, A Tale of Two States”, Economic and Political Weekly, 6-13 July, (1996) vol XXXI, p. 27

[15] Puri, R. "Reforming the Public Distribution System: Lessons from Chhattisgarh" Economic and Political Weekly, (2011) 47(5)

[16] Radharkrishna, R., \&Subbarao, K, “India's Public Distribution System: A National and International Perspective” World Bank Publications (2011) (vol 38)

[17] Radharkrishna, R., \&Subbarao, K. “India's Public Distribution System: A National and International Perspective” (1997) (Vol. 380). World Bank Publications.

[18] Ramaswami, B., \&Balakrishnan, P "Food Prices and the Efficiency of Public Intervention: the Case of the Public Distribution System in India”. Food policy, (2002), 27(5), p. 419-436. 
[19] Ray, S., \& Ray, I. A “Role and Effectiveness of Public Distribution System in Assuring Food Security in India: An Appraisal” (2011). Journal of Economics and Sustainable Development, 2(4), 238-251.

[20] Srivastava, "CCL (Cash Credit Limit) FOR BPL (Below Poverty Line) and APL (Above Poverty Line) Population: An Alternative to Universal PDS (Public Distribution System) In India”, International Journal of Politics and Good Governance (2010), Volume 1, No. 1.3 Quarter III ISSN No. 0976 - 1195.

[21] Svedberg, P. “Reforming or Replacing the Public Distribution System with Cash Transfers?” Economic \& Political Weekly, (2012), 47(7), p. 53-62

[22] Srinivasa, S. and Mahendra Kumar, S., "Food Security in India - An Analysis", Third Concept, March 2000, 24(277), p. 13-18.

[23] Tritah, A (2003) "The Public Distribution System in India: Counting the poor from making the poor count". Toulouse, France: Universite des Sciences Sociales, Groupe de Recherche en EconomieMathématique et Quantitative.

[24] National Institute of Rural Development (2003). “A study on Leakages in Targeted PDS in Rural India” Hyderabad.

[25] Tripathy, K.K., "Food Security and Food Management in India: A Review”, Kurukshetra, June 2008, 56(8): 3.

[26] Upadhyay. V "Inflation, Food Security and Public Distribution System", Social Action, (1996) Vol.6, No: 3. Reports

[27] Food and Agricultural Organization (FAO) Report 2014-16

[28] Economic Survey 2008-09, Government of India. Ministry of Finance

[29] Kanyakumari District Statistics Report 2011-2012

[30] Planning Commission, (2001). Planning Commission.gov.in/ report/ fiveyrs/ tenthplan/ Targeted public distribution system.

[31] National Corporate Social Responsibility Hub, (2011). School of Managementand Labour Studies Tata Institute of Social Sciences, Mumbai.

[32] Government of India (2010-11) Economic survey and Annual report on department of economics and statistics

[33] Government of India (2002): Report of the High Level Committee on Long - Term Grain Policy.

[34] Department of Food and Public Distribution, M/o Consumer Affairs, Food and Public Distribution.

[35] Performance Evaluation of Targeted Public Distribution System, Planning Commission report 2000

Website

[36] www.tncsc.tn.gov.in/

[37] www.tn.gov.in

[38] pdsportal.nic.in

[39] www.fcamin.nic.in

[40] www.inflibnet.ac.in 